\title{
EFEKTIFITAS PROMOSI DESTINASI WISATA REKREASI GUNUNG PANCAR MELALUI POSTINGAN INSTAGRAM MEDIA SOSIAL
}

\section{THE EFECTIVENESS OF THE PROMOTION OF A TOURIST DESTINATION PANCAR MOUNTAIN RECREATION THROUGH SOCIAL MEDIA POSTING (INSTAGRAM)}

\author{
Rahmi Fauziah'1a, IA Ratnamulyani², AA Kusumadinata ${ }^{3 a}$ \\ 123Program studi Ilmu Komunikasi Fakultas Ilmu sosial dan Ilmu Politik, Universitas Djuanda Bogor \\ JL.Tol Ciawi No 1 Kotak Pos 35 Bogor 16740 \\ 13aKorespondensi: Rahmi Fauziah, Email : rahmiifj@gmail.com \\ AA Kusumadinata, Email: alialamsyahkusumadinata@gmail.com
}

(Diterima: 02-03-2018 ; Ditelaah: 15-03-2018; Disetujui: 21-03-2018)

\begin{abstract}
The use of social media lately became much in demand by the community as a means to communicate, such as Instagram which is the social media that is widely used by users as a medium to post various images, at this time a lot of instagram users who make it as one of the media campaign. This promotional media is also used by the owner in Mount Pancar to attract tourists. And the interesting development of the natural tourism sector of this mountain of pancar became one of the economic support for the community, pick up section in the maintenance of these tours and especially economic support in the area of Bogor Regency. The purpose of this study To determine the effectiveness of promotions recreational tourist destination mount Pancar through Instagram posting. The results of the research was promoted through instagram as a social media that tends to have many users ware considered effective to be used as a new media to promote marketing.
\end{abstract}

Keywords: Campaign Effectiveness, Instagram, Marketing Communication,

\begin{abstract}
ABSTRAK
Penggunaan media sosial belakangan menjadi banyak diminati oleh masyarakat sebagai sarana untuk berkomunikasi, seperti Instagram yang merupakan media yang sering digunakan oleh penggunanya sebagai media untuk memposting beragam gambar, pada saat ini banyak sekali pengguna instagram yang menjadikan nya sebagai salah satu media promosi. Media promosi ini juga digunakan oleh owner di gunung pancar untuk menarik wisatawan. Dan menariknya berkembangnya sektor pariwisata alam Gunung pancar menjadi penunjang ekonomi bagii masyarakat yang ikut andil dalam pemeliharaan wisata tersebut dan khususnya penunjang ekonomi di wilayah Kabupaten Bogor. Tujuan penelitian ini Untuk mengetahui efektifitas promosi destinasi wisata rekreasi gunung pancar melalui postingan Instagram. Adapun hasil dari penelitian menunjukkan bahwa promosi melalui instagram sebagai media sosial yang cenderung memiliki banyak penggunanya sehingga dirasa efektif untuk dijadikan media baru untuk melakukan promosi pemasaran.
\end{abstract}

Kata kunci : Efektivitas Promosi, Instagram, Komunikasi Pemasaran 
R Fauziah, IA Ratnamulyani, AA Kusumadinata. 2018. Efektifitas Promosi Destinasi Wisata Rekreasi Gunung Pancar Melalui Postingan Instagram Media Sosial. Jurnal Komunikatio 4(1): 27-40 


\section{PENDAHULUAN}

Mentri pariwisata saat tahun 2016 mengatakan Pertumbuhan pariwisata indonesia yang melebihi rata-rata dunia, sebagaimana tercatat dunia pada tahun 2015 sebesar 10,63\% sehingga kementrian pariwisata semakin percaya diri untuk meningkatkan target kunjungan wisatawan mancanegara pada tahun 2016 dari 10 juta menjadi 12 juta. Pada saat ini kondisi kepariwisataan nasional secara makro menunjukan perkembangan dan kontribusi yang terus meningkat dan semakin signifikan terhadap PDB (Poduk Domestik Bruto) nasional sebanyak $4,23 \%$ atau senilai Rp. 461,36 Triliun. Pada kondisi mikro, jumlah wisatawan mancanegara (wisman) meningkat sebanyak 10,4 juta wisatawan mancanergara dan wisatawan nusantara sebanyak 255,20 juta perjalanan. (Kemenpar 2015)

Wisata alam merupakan salah satu bentuk hasil dari memanfaatkan potensi sumberdaya alam baik dalam keadaan alami maupun setelah terjadinya proses budidaya, sehingga wisatawan memungkinkan memperoleh kesegaran jasmaniah dan rohaniah, mendapatkan pengetahuan serta pengalaman dan menumbuhkan cinta terhadap alam (Anonymous 1993).

Namun Berkembangnya sektor pariwisata alam tidak selamanya diketahui oleh calon wisatawan. Sekian banyak wisata dan rekreasi, wisatawan mancanegara maupun wisatawan nusantara hanya mengetahui destinasi wisata yang sudah terkenal seperti Bandung Lodge Of Maribaya, Wakatobi, dan Lombok. namun jika ditelusuri lebih lanjut, potensi wisata rekreasi diindonesia sangat kaya namun pada kegiatan promosi masih terbilang sangat minim, dan kurangnya data informasi yang diperlukan dalam pengembangan wisata (Sutanto 2013). Hal inilah yang menyebabkan wisata alam dan rekreasi di Indonesia yang berlimpah sangat jarang diketahui keberadaannya seperti salah satunya wisata alam Gunung Pancar.

Upaya yang dilakukan untuk memperkenalkan pariwisata alam dan rekreasi ialah melalui komunikasi pemasaran. Komunikasi pemasaran sangat dibutuhkan untuk menyampaikan pesan kepada publik, terutama wisatawan sasaran, mengenai keberadaan suatu objek wisata. Salah satu pemasaran yang digunakan adalah dengan melakukan kegiatan promosi. Tujuan dari kegiatan promosi itu sendiri adalah memengaruhi calon wisatawan untuk mau berkunjung serta menjaga agar wisatawan selalu ingat dan berkeinginan untuk melakukan kunjungan kembali (Sukmawati 2013)

Cara-cara konvensional seperti poster, pamflet, dan flyer dianggap tidak efektif karena harganya yang relatif mahal dan penyebaran informasi yang sifatnya lamban dan seiring berkembangnya zaman, media penyiaran dan media konvensional mulai mengalami degradasi dan penyusutan dengan diambil alihnya sebagian peran-peran dengan teknologi yang lebih baru dan fitur yang lebih kaya. Media tersebut dinamakan media sosial. Media sosial mampu menyebarkan informasi dengan cepat dan daya jangkau yang luar biasa dibandingkan dengan media manapun. Media sosial banyak ragamnya antara lain instagram, facebook, twitter, website dan lain-lain.

Penggunaan media sosial tersebut belakangan menjadi banyak diminati oleh masyarakat sebagai sarana untuk 
berkomunikasi, salah satunya yaitu Instagram merupakan salah satu media sosial yang banyak digunakan oleh penggunanya sebagai media untuk memposting beragam gambar, pada era millenia banyak sekali pengguna instagram yang menjadikan nya, bagian dari media promosi. Media promosi ini juga digunakan oleh salah satu owner di gunung pancar untuk menarik wisatawan. wisatawan Gunung pancar pada saat ini bertambah, perpindahan promosi dari cara konvensional ke cara sosial network yang mempengaruhi naiknya presentase wisatawan Gunung pancar tersebut.

Dengan begitu adanya instagram sebagai sosial media yang dijadikan media untuk berpromosi maka objek wisata rekreasi Gunung pancar mulai memperluas destinasi wisatanya, di mulai dengan wisata pemandian air panas, kini wisata alam gunung pancar membuka wisata rekreasi sama halnya seperti wisata Lodge of Mariabaya di Bandung dengan menyiapkan beragam spot untuk berfoto. Dengan berkembangnya sektor pariwisata alam gunung pancar ini tentunya menjadi salah satu penunjang ekonomi bagi masyarakat yang ikut andil dalam pemeliharaan wisata tersebut dan khususnya penunjang ekonomi di wilayah Kabupaten Bogor.

Penelitian yang telah dilakukan sebelumnya menunjukan manfaat dari penggunaan media sosial. Penelitian dari Fatanti dan Suyadnya (2015) menunjukan bagaimana Instagram membuat destinasi merek pariwisata di Indonesia khususnya di Bali dan Malang. Instagram berguna untuk mendorong promosi sebuah tempat menjadi tujuan wisata. Adanya fasilitas dalam Instagram seperti fotografi, geotagging, geolocation, hashtag, dan suka dapat mempermudah bagi pengguna atau wisatawan untuk mencari informasi tentang lokasi tujuan wisata. Semua fasilitas yang telah ditawarkan oleh Instagram memiliki potensi yang mendukung dan menciptakan destination brand, terutama di bidang pariwisata. Pengguna berdasarkan media sosial atau User Generated Content (UGC) melalui media sosial dapat menciptakan minat terhadap produk dan tujuan. Seperti dalam penggunaan dikedua akun yang dimiliki oleh admin Bali dan admin Malang yang dijelaskan dengan melalui Instagram keduanya memiliki potensi untuk melanjutkan, mengembangkan dan membuat gambar baru untuk tujuan pariwisata di Instagram.

Sedangkan Menurut Widyaningrum (2016) mengatakan secara finansial lebih efisien dan praktis Strategi pemasaran yang memanfaatkan kemajuan teknologi informasi, salah satu caranya adalah dengan mengunakan media sosial. Mempromosikan menggunakan media sosial selain tidak berbayar juga dapat menjaring pelanggan baru penguna media sosial. Oleh karena itu penelitian ini bertujuan untuk mengetahui efektifitas promosi destinasi wisata rekreasi gunung pancar melalui postingan instagram sebagai media sosial.

\section{Kerangka Teori}

Menurut Morissan (2010), Promosi adalah salah satu bagian dari strategi pemasaran yang sering dikenal dengan istilah four P's yaitu produk (product), harga (price), distribusi (place), dan promosi (promotion). Menurut Nisrina (2015). Makin populernya Instagram sebagai aplikasi untuk berbagi foto membuat banyak pengguna yang memiliki bisnis online turut mempromosikan produk- 
produknya lewat Instagram. Instagram pun dijadikan sebagai media pilihan oleh pengelola wisata Rekreasi Gunung pancar sebagai media yang dipilih untuk mempromosikan destinasi yang terdapat di Gunung pancar.

Menurut Lewis (2010), media sosial merupakan teknologi digital yang memungkinkan orang untuk berinteraksi, dan berbagi isi pesan. Media sosial merupakan istilah yang banyak digunakan setiap penggunanya untuk saling mengikat dan berinteraksi melalui isi pesan yang berbasis web.

Pelaku usaha Pariwisata melakukan promosi melalui media sosial seperti memberikan informasi, promo produk event dan melakukan perbincangan dengan konsumen secara intensif dengan tujuan memberikan layanan prima pada konsumen sampai akhirnya terjadinya transaksi bahkan transaksi berulang. Sebuah promosi dapat dilakukan dengan berbagai macam cara mulai dari cara konvensional atau cara langsung dan melalui internet. Sebelum adanya internet, sebuah promosi dilakukan langsung melalui pembicaraan kepada orang-orang (Word of Mouth), melalui media cetak, televisi, radio dan lainnya. Sekarang ini banyak pelaku usaha Pariwisata yang melihat beberapa keuntungan dari promosi melalui media social, maka dari itu para pelaku usaha mulai berpindah dari cara konvensional ke social network.

Menurut Widyaningrum (2016) pada penelitian Peran Media Sosial sebagai Strategi Pemasaran pada Sewa Kostum Meiyu Aiko Malang mengatakan Hasil penelitian menunjukkan marketing online dilakukan melalui facebook, twitter, Instagram dan Website mempunyai dampak positif terhadap penjualan pada jasa mereka. Selain itu Facebook dapat memberikan informasi yang cepat pada konsumen Meiyu Aiko, Facebook juga dimanfaatkan sebagai buzz marketing karena banyak konsumen yang mengungah foto self picture (Selfi) dengan kostum dan merekomendasikan pada kerabatnya. Menerapakan strategi pemasaran dengan menggunakan media sosial berbasiskan jejaring sosial dan website sangat efisien karena mendapatkan peluang konsumen potensial yang lebih tinggi daripada menggunakan strategi pemasaran konvesional

\section{METODE PENELITIAN}

Penelitian ini menggunakan pendekatan kualitatif, penelitian kualitatif adalah tradisi tertentu dalam ilmu pengetahuan sosial yang secara fundamental bergantung pada pengamatan terhadap manusia dalam kawasannya sendiri dan berhubungan dengan orang-orang tersebut dalam bahasanya dan dalam peristilahannya. Pendekatan kualitatif dilakukan dengan wawancara mendalam (In-depth Interview) dengan informan dengan atau tanpa menggunakan pedoman wawancara (interview Guide) dan peneliti melakukan observasi langsung (Moleong 2012).

Metode pada penelitian ini menggunakan metode deskriptif yaitu menggambarkan kekuatan proses promosi destinasi wisata alam dan rekreasi gunung pancar melalui instagram dengan melihat bagaimana respon pengguna Instagram lainnya dan peneliti akan melihat sejauh mana efektifitas promosi yang dilakukan oleh akun@gunungpancar. 
Sugiyono (2012) penelitian deskriptif adalah penelitian yang dilakukan untuk mengetahui nilai variabel mandiri, baik suatu variabel atau lebih (independent) tanpa membuat perbandingan atau menghubungkan dengan variabel lain. Wawancara penelitian ini dilakukan pada 5 (lima) orang yaitu Widiyanto sebagai pengelola PT. Wana Wisata Indah Gunung Pancar, Ajud sebagai pemilik spot foto, Heru Herdianto sebagai penjaga spot foto, Selanjutnya Abd.Kodir dan Salwa Azizah Nurfatma sebagai wisatawan.

Analisis data dalam pendekatan
ualitatif didahului oleh upaya

mengungkapakan trustworthiness dari para subjek penelitian. Dengan menguji kebenaran dan kejujuran subjek penelitian dalam mengungkap realitas. Trustworthiness ini diuji melalui pengujian: kebenaran subjek, dengan menguji jawaban-jawaban pertanyaan berkaitan dengan pengalaman dan pengetahuan mereka yang khas. Berikutnya adalah menguji authenticity, yaitu peneliti memberi memfasilitasi dan kesempatan pengungkapan konstruksi personal yang lebih detail (Kriyantono 2012).

\section{HASIL DAN PEMBAHASAN}

\section{Komunikasi Pemasaran di Wisata Rekreasi Gunung Pancar}

\section{Instagram sebagai Media Komunikasi Pemasaran}

Penggunaan media sosial tersebut belakangan menjadi banyak diminati oleh masyarakat sebagai sarana untuk berkomunikasi, salah satunya yaitu Instagram merupakan media sosial yang sering digunakan oleh penggunanya sebagai media untuk memposting beragam gambar, pada saat ini banyak sekali pengguna instagram yang menjadikan nya sebagai salah satu media promosi. Media promosi ini juga digunakan oleh salah satu owner di gunung pancar untuk menarik wisatawan. wisatawan Gunung pancar pada saat ini bertambah, perpindahan promosi dari cara konvensional ke cara sosial network yang mempengaruhi naiknya presentase wisatawan Gunung pancar tersebut. Dengan begitu adanya Instagram sebagai sosial media yang dijadikan media untuk berpromosi maka objek wisata rekreasi Gunung pancar mulai memperluas destinasi wisatanya, di mulai dengan wisata pemandian air panas, kini wisata alam gunung pancar membuka wisata rekreasi sama halnya seperti wisata Lodge of Mariabaya di Bandung dengan menyiapkan beragam spot untuk berfoto.

Menurut Puspitorini (2016), Sukrillah et al. (2017) bahwa media sosial merupakan media online yang terhubung dengan jaringan internet yang mempublikasikan konten, seperti profil, data, dan aktifitasaktifitas pengguna serta sebagai media berkomunikasi dan berinteraksi tanpa batas geografis ruang dan waktu. Internet adalah simbol dari media baru. Internet mempermudah manusia dalam mendapatkan informasi dari belahan dunia dengan cepat dan dapat menghubungkan, mempertemukan banyak orang dari berbagai negara. Tentunya, ini terwujud karena adanya jaringan komputer. Manfaat internet diantaranya untuk media informasi dan komunikasi, tidak hanya itu internet 
dimanfaatkan dalam bidang bisnis, ekonomi, organisasi, pendidikan dll.

Sedangkan menurut Widyaningrum (2016) tidak hanya menawarkan kemudahan saja, Konteks pemasaran secara online juga menawarkan konten media baru dalam media komunikasi pemasarannya. Media baru dalam dunia pemasaran saat ini adalah media sosial. Pada penelitian ini, peneliti melihat bagaimana media sosial khususnya Instagram memiliki keunggulan jika dibandingkan media sosial lain dalam hal pemasaran secara online. Facebook merupakan sebuah aplikasi tidak berbayar yang mengedepankan kemudahan akses pada fiturnya, jika dibandingkan dengan media sosial lainnya seperti Instagram ataupun Twitter.

\section{Keunggulan Instagram dalam media komunikasi}

Instagram adalah media yang memberi kemudahan cara berbagi secara online oleh foto-foto, video dan juga layanan jejaring sosial yang mudah digunakan oleh penggunanya serta mengambil dan membagi ke teman mereka (Budiargo 2015). Menurut situs Instagram, aplikasi Instagram didirikan oleh Kevin Systrom dan Mike Krieger. Aplikasi yang dirilis pada Oktober 2010. Instagram merupakan aplikasi yang untuk berbagi foto atau gambar kepada temanteman sesama pengguna instagram foto-foto yang telah di upload ke instagram bisa dilihat kembali kedepannya sebagai kenangan yang sedang terjadi dan telah terjadi. Pengguna media sosial Instagram berkomunikasi dengan cara memberikan komentar dan like pada hasil foto maupun video yang telah diunggah.

Instagram adalah jejaring sosial yang digunakan sebagai tempat menyebarkan dan berbagi informasi, berinteraksi dengan orang banyak, serta dapat mengenal lebih dekat dengan sesama pengguna Instagram melalui foto-foto, video yang diunggah. Tampubolon (2016), instagram termasuk media yang low cost dibandingkan TV, Radio, Majalah, Billboard, dll. Instagram pun cepat dan efektif dalam menjangkau audiens yang sangat luas. Dengan menggunakan instagram, penggunannya juga dapat melakukan kegiatan share, sehingga berita maupun informasi yang akan disebar dapat tersebar secara luas. Dan yang terakhir adalah karena instagram dapat dianggap sebagai jalan pintas untuk menghemat waktu serta energi bagi beberapa eksternal maupun internal.

Putri (2013), Pasar yang melek teknologi menjadikan instagram sebagai salah satu kelebihan yang spesifik dalam melakukan pemasaran melalui instagram. Salah satu kelebihan berjualan lewat Instagram adalah pengguna Instagram sudah 'terjamin' melek teknologi. Artinya, pengguna instagram adalah mereka yang pasti aktif dan memiliki akun di Twitter dan juga Facebook. Karena itu, mengapa instagram dikatakan sangat tepat untuk mempromosikan produk dan dibantu jejaring sosial lainnya,para Pengguna Instagram pastilah mereka yang memiliki gadget yang mendukung aplikasi tersebut, seperti android maupun iPhone. Dan hal itu sudah menjelaskan secara tidak langsung bahwa pengguna instagram adalah mereka yang rqata-rata memiliki kondisi ekonomi menengah keatas. Hal ini menguntungkan bagi penjual, karena calon konsumen pasti mempunyai 'kantong' yang cukup dalam, display produk yang sederhana. Instagram hanya didesain sebagai aplikasi untuk berbagi foto dan fitur-fitur di Instagram akan mendukung gambar produk yang di upload di dalamnya 
seprti fitur filter.,dan padea proses pengunggahan foto di instagram pun banyak dari mereka menggunakan fitur hastag. agar memudahkan calon pembeli menemukan produk penjual.

\section{Kelemahan Instagram}

Menurut website kingpromosi.com (2015) kekurangan Instagram sebagai media online shop yaitu:

1. Harus update secara berkala

Sama halnya seperti twitter, instagram memiliki timeline yang berjalan sangat cepat juga. Hal ini menjadikan para penggunanya khususnya pemilik online shop harus selalu melakukan posting foto atau video agar produk dapat dilihat oleh konsumen.

\section{Spamming (Sampah Berita)}

Spamming banyak terjadi pada kolomkolom komentar. Dan intagram memberikan kemudahan dengan cara anda dapat menyiasatinya dengan mengaktifkan private pada akun anda agar sembarang pengguna tidak dapat berkomentar pada postingan anda.

\section{Transaksi yang kurang praktis}

Seperti yang telah kita ketahui bahwa Instagram tidak dirancang sebagai media untuk melakukan jual beli, jadi wajar jika proses transaksinya tidak praktis. Oleh karena itu, diwajibkan pemilik akun online shop untuk menyertakan kontak pada bagian profile dan caption pada setiap postingan.

4. Persaingan yang ketat

Saat ini, melihat semakin banyak pengguna instagram para pemilik online shop di instagrampun semakin banyak,. Hal ini yang menjadikan nya banyak memiliki persaingan karena calon konsumen akan dengan mudah menemukan online shop yang sejenis dengan milik anda. Dengan pelayanan yang ramah serta harga dan kualitas barang yang baik adalah kunci utama untuk tetap mempertahankan lebih banyak konsumen.

Sama halnya dengan promosi penjualan barang di online shop, PT.Wana Wisata Gunung Pancar mendapati beberapa kekurangan menggunakan instagram yang dijadikan sebagai salah satu media untuk melakukan promosi wisata rekreasi gunung pancar tersebut, salah satunya yaitu pihak pengelola wisata dan pemilik aku @gunungpancar disarankan untuk melakukan update secara berkala mengenai informasi-informasi wisata yang ada di gunung pancar, dengan jangka waktu satu minggu tidak mengupdate atau meng-upload foto mengenai wisata tersebut, pihak pengelola akan kehilangan beberapa like bahkan followers yang ada.

Spamming pasti akan selalu terjadi pada seluruh akun media social lainnya, bahkan instagram tidak pernah lepas dari spamming komentar, karena semakin banyak menggunakan fitur hastag, dan geotagging semakin banyak yang bisa mengakses hasil gambar yang telah diUpload. Biasanya spamming komentar dilakukan oleh para penjual yang melakukan promosi melalui instagram juga.

Instagram memang tidak dirancang untuk dijadikan sebagai wadah jual beli maka transaksi jual beli pada akun instagram cenderung kurang praktis, PT.Wana Wisata Gunung Pancar pada akun nya @gunungpancar harus menambahkan caption yang melengkapi sebuah gambar yang ada, agar followers dapat lebih memahami maksud dari foto yang di upload tersebut. Dan tentunga dengan menggunakan fitur flagging akan semakin membuat para pengunjung atau followers mudah mengakses jalan menuju wisata rekreasi gunung pancar tersebut. 
Seperti halnya berjualan barang dan jasa lainnya, pihak pengelola wisata rekreasi Gunung Pancar pun memiliki banyak pesaing ketat, terutama para pemilik spot foto yang banyak ragamnya, dengan beragam spot foto yang berbeda yang mereka tawarkan di masing-masing akun instagram yang telah dimiliki semakin besar tingkat persaingan yang terjadi.

\section{Fungsi instagram selain mode komunikasi pemasaran}

Seperti yang telah kita ketahui fungsi utama dari Instagram adalah untuk mengunggah dan berbagi foto serta video pada pengguna lainnya. Namun saat ini Instagram memiliki beberapa fungsi lain yang selalu digunakan para pemilik akun di sosial media Instagram, seperti akun @gunungpancar yang menjadikannya sebagai sarana komunikasi pemasaran, promosi, dan akun-akun lain yang menjadikannya sebagai sarana berjualan online selain itu insatgram pun dapat dijadikan sebagai sarana media dakwah. Namun, instagram memiliki peraturan tertentu agar pengguna dari Instagram tidak mengundah foto-foto yang tidak sesuai dengan peraturan. Peraturan yang paling penting di dalam Instagram adalah foto yang berbau fornografi sangat dilarang untuk di upload dalam instagram dan juga merepost atau mengupload foto orang lain tanpa meminta izin terlebih dahulu.

Menurut Mahendra (2017), Sukrillah et al. (2017), Instagram sama halnya dengan situs pertemanan lainnya, Instagram juga memiliki beberapa fungsi utama sebagai media sosial. fungsi utama dari Instagram yaitu publikasi kegiatan sosial dan organisasi. Sidiq (2017), akun instagram @fuadbakh menggunakan fitur format video, gambar, captions, mentions, hastag, dan fitur comment dalam memanfaatkan Instagram sebagai sarana untuk berdakwah dan dijadikannya sebagai media untuk menyebarkan pesan-pesan islamiyah secara efektif. Dan strategi yang paling diandalkan dalam pembuatan konten dan pemilihan tema cinta dan satu hal yang sedang menjadi tren dikalangan masyarakat Indonesia agar khalayak dapat melihat perspektif tersebut dari perspektif islam.

\section{Efektifitas Instagram Media Sosial sebagai Media Promosi}

Efektivitas merupakan hasil akhir yang dapat di rasakan dari berhasil atau tidaknya strategi yang telah direncanakan sebelumnya. Hasil yang semakin dekat dengan sasaran yang diinginkan menunjukan derajat efektivitas yang semakin tinggi. (Arthur dan Raymond 1991). Dengan dibukanya wisata alam rekreasi di Gunung Pancar ini pihak pengelola berharap agar masyarakat dapat memanfaatkan lahan untuk dijadikan tempat wisata tanpa merusak alam, dengan begitu bisa membantu taraf ekonomi masyarakat sekitar. Hal ini untuk memperkenalkan ekosistem hutan pinus dan vegetasi lainnya pihak PT. Wana Wisata Indah melakukan promosi melalui Instagram sebagai salah satu media yang dianggap cukup efektif.

Faisal (2017) mengatakan bahwa saat ini Instagram tidak hanya dijadikan sebagai salah satu cara untuk bersosialita dengan dunia maya, tetapi bisa dijadikan sebagai alternatif baru dalam melancarkan aksi bisnis, seperti melakukan pemasaran tentunya. Walaupun sampai saat ini facebook masih memiliki pengguna 
terbanyak, tetapi instagram mampu menawarkan lebih dari sekedar fitur pertemanan itu. Saat ini dengan hadirnya Instagram Blog, memberi kemudahan kepada setiap pengguna nya dalam melakukan langkah-langkah pemasaran. Beberapa hal yang bisa didapatkan dengan facebook. Itu sebabnya pebisnis Amerika menjadikan instagram sebagai salah satu pilihan terbaik dalam berbisnis dengan media sosial.

\section{Menurut Rahmawati} mengatakan bahwa fitur-fitur yang berada dalam akun Instagram efektif dan efisien untuk digunakan sebagai media promosi, seperti geotagging, arroba,followers, following, hastag, like, dan explore dengan menggunakan pendekatan komunikasi pemasaran inipula lah, hal tersebut bisa tejadi .

Dengan menggunakan pendekatan Four $P$ yaitu product (produk), Price (Harga), Place (Tempat), Promotion (Promosi).

1. Product (Produk) yaitu suatu hal yang ditawarkan baik itu baranng dan jasa, pada penelitia ini produk yang ditawarkan yaitu lokasi spot foto yang berada di kawasan pegunungan di wilayah kecamatan babakan madang, yaitu spot foto gunung pancar. Dengan menggunakan inovasi baru PT. Wana Wisata Indah Gunung Pancar menggunakan fitur Filter gambar yang ada di aplikasi instagram sehingga barang / produk yang ditawarkan menarik pengunjung dan calon pengunjung. Pada saat ini instagram dilengkapi dengan fitur Story Ig,Live Boomerang, Super Zoom, Rewind dan lain-lain. Hal ini lebih mudah penjual memasarkan produk karena setiap followers ataupun bukan dapat melihat hasil gambar yang telah di upload.

2. Price (Harga), mengapa memilih instagram sebagai salah satu aplikasi untuk dijadikan bahan promosi oleh PT.Wana Wisata Indah, karena dengan menggunakan kecanggihan internet dan melihat pada saat ini lebih banyak orang yang menggunakan, hal itu menjadikan promosi melalui instagram lebih efisien karena tidak perlu memperhatikan ruang dan waktu. Dengan menggunakan instagram pun, hanya memerlukan seberapa banyak followers yang kita miliki, dan menggunakan fitur Geotagging membuat semua orang dapat mengakses dan mengetahui lokasi wisata tersebut.

Sulianta (2014), Pemasaran produk industri pariwisata jauh lebih kompleks sifatnya dibandingkan dengan memasarkan produk perusahaan manufaktur yang umumnya memproduksi produk berwujud. Caracara konvensional saat ini mulai diambil alih oleh kecanggihan tekhnologi dengan teknologi yang lebih baru dan fitur yang lebih kaya membuat cara konvensional mulai ditinggalkan dan itu menjadi sdalah satu keunggulan dalam melakukan promosi menggunakan social network.

3. Place (Tempat/lokasi), lokasi menjadi perhatian dan pertimbangan khusus untuk pemilik usaha Wisata Gunung Pancar ini, dengan melihat perkembangan dan permintaan konsumen maka pemilik usaha berusaha mencocokan bagaimana cara agar konsumen tertarik berkunjung ke daerah pegunungan dengan suasana yang berbeda. Dan pada akun instagram 
@gunungpancar pihak PT.Wana Wisata Indah menggunakan Fitur add location untuk mempermudah calon pengunjung dating ke lokasi spot foto gunung pancar tersebut, dengan fitur tersebut akan langsung terakses ke google maps.

4. Promotion (promosi) adalah yang terpenting dari setiap proses penjualan barang maupun jasa, pihak PT.Wana Wisata Indah maupun pengelola spot foto melakukan promosi melalui instagram dengan menggunakan hampir semua fitur yang ada di instagram sepeti geotagging,hastag, arroba, judul foto,explore dan menggunakan fitur tagging ke akun lain. Sehingga followers akan semakin bertambah, dengan banyak nya like pun akan mempengaruhi proses promosi tersebut.

Wisata alam gunung pancar merupakan wisata alam yang dikelola oleh PT. Wana Wisata Indah, perhutani dan bekerjasama dengan masyarakat sekitar. Dengan Menawarkan panorama alam hutan sebagai media kreasi dan rekreasi serta Mengenalkan ekosistem hutan pinus dan vegetasi lainnya kepada pengunjung maupun masyarakat sekitar khususnya generasi muda agar lebih menghargai dan mencintai alam.

\section{KESIMPULAN DAN SARAN}

\section{Kesimpulan}

Promosi dikatakan berhasil dengan menggunakan Instagram dan dikatakan efektif, dengan melihat kemajuan teknologi yang selalu diperbarui melalui Instagram dengan memiliki banyak pengguna. Banyak perusahaan yang mengambil keuntungan dari fitur-fitur yang ada didalam Instagram dengan pelibatan masyarakat langsung sehingga mampu mendapatkan penghasilan bagi masyarakat sekitar. Pendekatan produk, melalui 4P (product, place, price, dan promotion) melalui media sosial Instagram mampu mendatangkan beragam wisatawan dari berbagai daerah.

\section{Saran}

Rekomendasi dalam penelitian ini adalah sebaiknya lebih mengembangkan inovasi-inovasi baru dalam promosi khusunya melalui media sosial Instagram dengan menggunakan semua fitur yang ada didalamnya sehingga lebih menarik dalam uploading foto dengan melibatkan masyarakat dan pengunjung. 


\section{DAFTAR PUSTAKA}

Anonymous. 1993. Peluang dan Tantangan Ekspor Produk Perikanan Indonesia di Pasar Internasional pada Era PJPT II. (Makalah Seminar Nasional). Yogyakarta (ID) : University Club. UGM.

Arthur GG, Raymond FZ, 1991. Organization Theory and Design. Jakarta (ID): Universitas Terbuka.

Budiargo D. 2015. Berkomunikasi ala Net Generation. Jakarta (ID): PT Elex Media Komputindo Kompas Gramedia.

Faisal M. 2017. Komunikasi Pemasaran Tugu Barbershop dengan Menggunakan Media Instagram. EJurnal Ilmu Komunikasi Universitas Mulawarman 5 (3): 413-425.

Fatanti MN, Suyadnya IW. 2015. Beyond User Gaze: How Instagram Creates Tourism Destination Brand?. Procedia - Social and Behavioral Sciences 211: 1089-1095. Tersedia di http://doi.org/10.1016/i.sbspro.2015. $\underline{11.145}$

[KEMENPAR] Kementrian Pariwisata. 2015. Rencana strategis Kementrian Pariwisata. Diunduh 30 november 2017 di situs www.kemenpar.go.id

Kingpromosi.com. 2015. Rajanya Promosi Online Shop di Instagram. Diunduh 18 maret 2018 di situs www.kingpromosi.com.

Kriyantono R. 2012. Public Relation \& Cirsis management (pendekatan critical public relation, etnografi kritis \& kualitatif). Jakarta (ID): Kencana, Perdana Media Group.
Lewis BK. (2010). Social Media and Strategic Communication : Attitudes and Perceptions Among College Student. International Journal of Public Relation Society of America,Vol 04, No.3 hal: 1-23.

Mahendra B. 2017. Eksistensi Sosial Remaja dalam Instagram (Sebuah Perspektif Komunikasi). Markerting Communications Garda Perdana Security 16 (156): :151 - 160.

Meolong L, 2012. Metodologi Penelitian Kualitatif. Bandung (ID): PT. Remaja Rosdakarya

Morissan AM. 2010. Periklanan komunikasi pemasaran terpadu. Jakarta (ID): Penerbit Kencana.

Nisrina M. 2015. Bisnis Online Manfaat Media Sosial dalam Meraup Uang. Yogyakarta (ID): KOBIS.

Puspitorini DA. 2016. Motif Dan Kepuasan Penggunaan Instagram (Studi Kesenjangan Antara Motif Dan Kepuasan Penggunaan Media Sosial Instagram Pada Mahasiswa Universitas Muhammadiyah Surakarta Angkatan 2013). Surakarta (ID) : Fakultas Komunikasi dan Informatika Universitas Muhammadiyah Surakarta :

Putri EAS. 2013. Aplikasi Instagram Sebagai Media Komunikasi Pemasaran Online Shop (Studi Deskriptif Kualitatif Aplikasi Instagram Sebagai Media Komunikasi Pemasaran Online Shop).[Skripsi]. Surabaya (ID) : Universitas Pembangunan Nasional 
"Veteran" Jawa Timur Fakultas Ilmu Sosial Dan Ilmu Politik.

Rahmawati D. 2016. Pemilihan dan pemanfaatan instagram sebagai media komunikasi online (studi seskriptif kualitatif pada akun instagram @freezebrown). [Skripsi], Bandung (ID).Universitas Negri Sunan Kalijaga,

Sidiq A. 2017. Pemanfaatan Instagram sebagai Media Dakwah (study akun @fuadbakh) [Skripsi]. Lampung (ID): Universitas Islam Negri Raden Intan Lampung, Fakultas Dakwah dan Ilmu Komunikasi.

Sugiyono. 2007. Metode penelitian kualitatif . Bandung (ID): Alfabeta.

Sukmawati L. 2013. Pengaruh kinerja bauran promosi terhadap keputusan menggunakan paket outbound di Ciwangun Indah Camp (survey pada wisatawan yang memutuskan menggunakan paket outbond).[Skripsi]. Bandung (ID) : Universitas Pendidikan Indonesia Fakultas Pendidikan Ilmu Pengetahuan Sosial.

Sukrillah A, Ratnamulyani IA, Kusumadinata AA. 2017. Pemanfaatan Media Sosial Melalui Whatsapp Group Fei Sebagai Sarana Komunikasi. Jurnal Komunikatio 3(2): 95-104.

Sulianta F. 2014. 101 Jurus Online Paling top. Jakarta (ID) Gramedia, Elex Media Komputindo

Sutanto F. 2013. 101 Jurus Promosi Online Paling Top. Jakarta [ID]: Elex Media Komputindo.

Tampubolon M, Putri YR, Atnan N.2016.Strategi Promosi Coffee Shop Melalui Media Sosial Instagram (Studi
Deskriptif PadaAkun @Crematology). e-Proceeding of Management 3 (2): 2421-2432.

Widyaningrum PW. 2016. Peran Media Sosial sebagai Strategi Pemasaran pada Sewa Kostum MeiyuAiko Malang. Al Tijarah 2 (2): 230-257. Tersedia di http://ejournal.unida.gontor.ac.id/ind ex.php/altijarah. 
